\title{
Fall Panicum: Biology and Control in Sugarcane ${ }^{1}$
}

\author{
D. Calvin Odero and Brent Sellers ${ }^{2}$
}

\section{Biology and Identification}

Fall panicum (Panicum dichotomiflorum) is the most prevalent and problematic annual grass weed in Florida sugarcane (Figure 1). It is a native grass that primarily emerges in spring and summer, but seed germination can occur almost year-round in Florida. It tends to be sensitive to shading and is typically not found in sugarcane once canopy closure occurs. Fall panicum typically reaches a height of 1.5 to 4 feet, but has been reported to reach over 6 feet in height. Its growth habit can range from erect to sprawling or kneeling, and it can form large, loose tufts. Seedlings and mature plants have different identifying characteristics. This publication describes the biology and control options for fall panicum in sugarcane to assist growers, county Extension faculty, and crop consultants in making correct identification and effective management decisions to help mitigate its impact on sugarcane.

\section{Seedlings}

The first seedling leaf blade is linear, nearly 5 times longer than its width, and parallel to the ground. The first few leaves of seedlings have many hairs on the underside. The sheaths and collars of the first few leaves also tend to be densely hairy (Figure 2). However, they gradually become less hairy as the seedling grows and new leaves emerge.

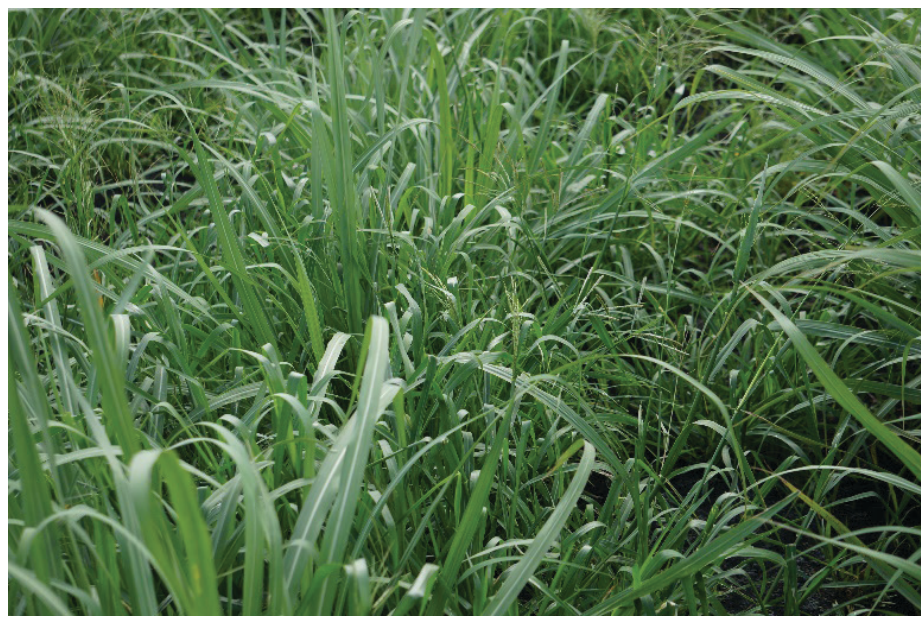

Figure 1. Fall panicum in a sugarcane field. Credits: Calvin Odero, UF/IFAS

Leaves are rolled in the bud, and auricles are absent. Leaf blades are $3 / 4$ to $1 \frac{1}{2}$ inches long and about $1 / 5$ inch wide. Ligules are $1 / 24$ to $1 / 12$ inch long, fringed, hairy, and often fused at the base.

\section{Mature Plants}

The leaf blades of mature plants are 4 to 20 inches long by $1 / 5$ to $4 / 5$ inch wide and have a conspicuous white midvein (Figure 3). The undersides of leaves on mature plants are without hairs (glabrous) and glossy. The ligule is a fringe of hairs (Figure 3). Stems are glabrous, round, and sometimes

1. This document is SS-AGR-132, one of a series of the Agronomy Department, UF/IFAS Extension. Original publication date August 2006. Revised July 2014 and February 2022. Visit the EDIS website at https://edis.ifas.ufledu for the currently supported version of this publication.

2. D. Calvin Odero, associate professor, Agronomy Department, UF/IFAS Everglades Research and Education Center; and Brent Sellers, professor, Agronomy Department, UF/IFAS Range Cattle Research and Education Center; UF/IFAS Extension, Gainesville, FL 32611.

The use of trade names in this publication is solely for the purpose of providing specific information. UF/IFAS does not guarantee or warranty the products named, and references to them in this publication do not signify our approval to the exclusion of other products of suitable composition.

All chemicals should be used in accordance with directions on the manufacturer's label.

The Institute of Food and Agricultural Sciences (IFAS) is an Equal Opportunity Institution authorized to provide research, educational information and other services

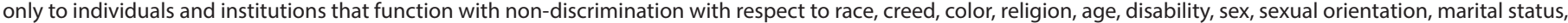
national origin, political opinions or affiliations. For more information on obtaining other UF/IFAS Extension publications, contact your county's UF/IFAS Extension office. U.S. Department of Agriculture, UF/IFAS Extension Service, University of Florida, IFAS, Florida A \& M University Cooperative Extension Program, and Boards of County Commissioners Cooperating. Andra Johnson, dean for UF/IFAS Extension. 
glossy. Nodes along the stem are usually swollen and bent in different directions (Figure 4), which contributes to the rather unusual zigzag growth habit of this weed. Roots are fibrous and stems are capable of rooting at the lower nodes only. The seed head is a wide, spreading panicle 4 to 16 inches long (Figure 5). Individual spikelets are yellow and approximately $1 / 8$ inch long by $1 / 12$ inch wide. Each spikelet produces 1 smooth, dull-yellow to brown seed that shatters soon after ripening. Propagation is by seeds. Seedling emergence primarily occurs from soil depths of 0 to 2 inches with most emerging at $1 / 2$ - to 1 -inch soil depths.

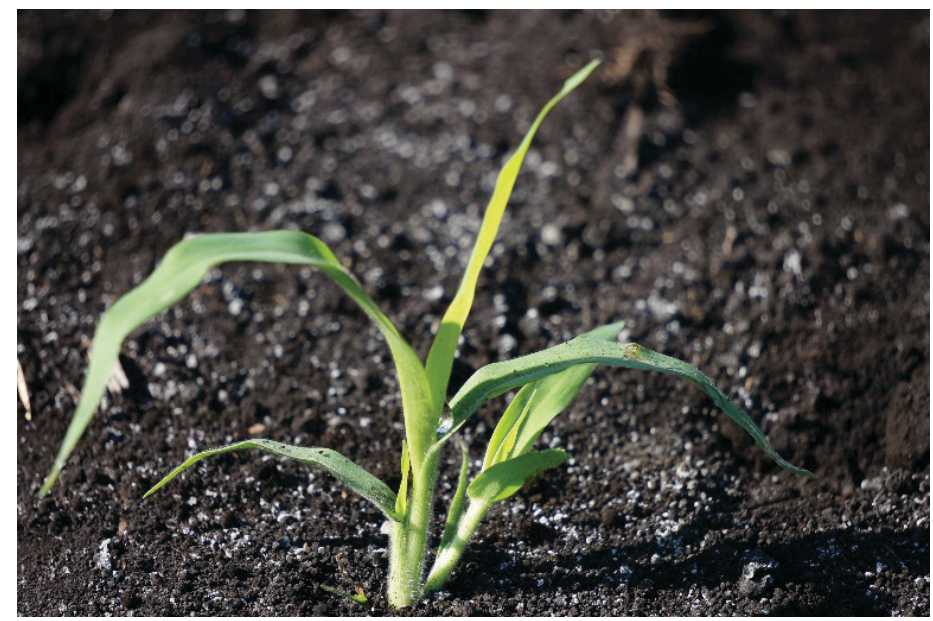

Figure 2. Fall panicum seedling with hairy sheath and collar. Credits: Calvin Odero, UF/IFAS

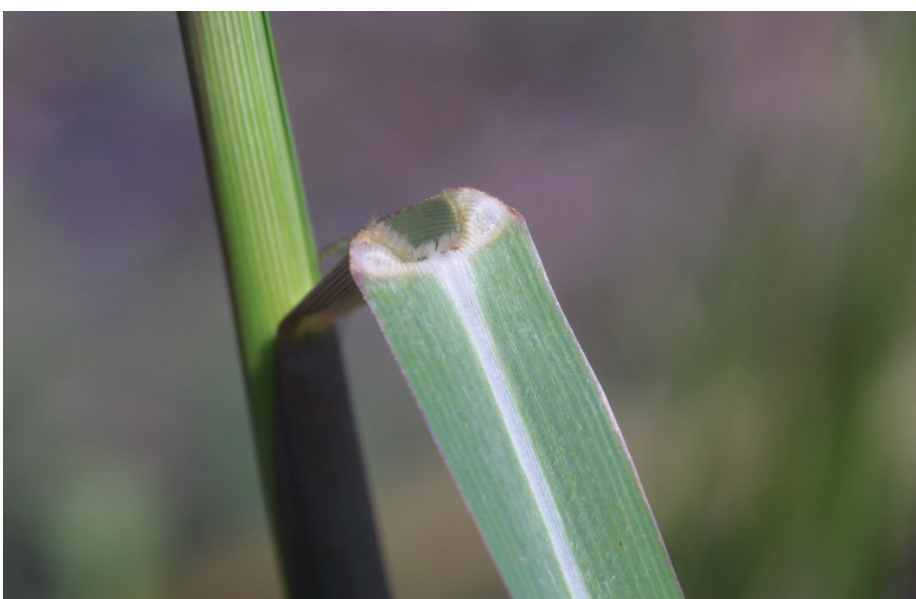

Figure 3. Fall panicum leaf with a prominent white midvein and hairy ligule.

Credits: Calvin Odero, UF/IFAS

\section{Control in Sugarcane}

Several herbicides applied at different timings will provide fall panicum control in sugarcane (Table 1). Therefore, proper timing of herbicide application with respect to the growth stage of fall panicum is very important for effective control. Always read the label for the proper time of application of each herbicide. These herbicides must be used in conjunction with other weed management tools such as crop rotation and mechanical cultivation to obtain maximum control benefit. In Florida, sugarcane is rotated with rice and winter vegetables including sweet corn, leafy greens, radish, and green bean during the crop's fallow renovation period. Sugarcane rotation with non-grass crops allows the use of graminicides (grass herbicides) such as sethoxydim (Poast $1.53 \mathrm{EC}$ ) to reduce populations of fall panicum in subsequent sugarcane crops. However, successive sugarcane planting (i.e., replanting several weeks after the final ratoon harvest) or rotating sugarcane with sweet corn or rice has caused fall panicum to increase in subsequent sugarcane crops (Odero, personal observation). Fall panicum seedlings are readily controlled by mechanical cultivation early postemergence in plant cane using scratcher cultivators, or between rows for ratoon sugarcane. However, herbicides have to be banded over the rows to provide fall panicum control within the rows, which are not cultivated. Because fall panicum is not shade tolerant, healthy competitive sugarcane stands with the ability to close canopy and shade it will enhance control.

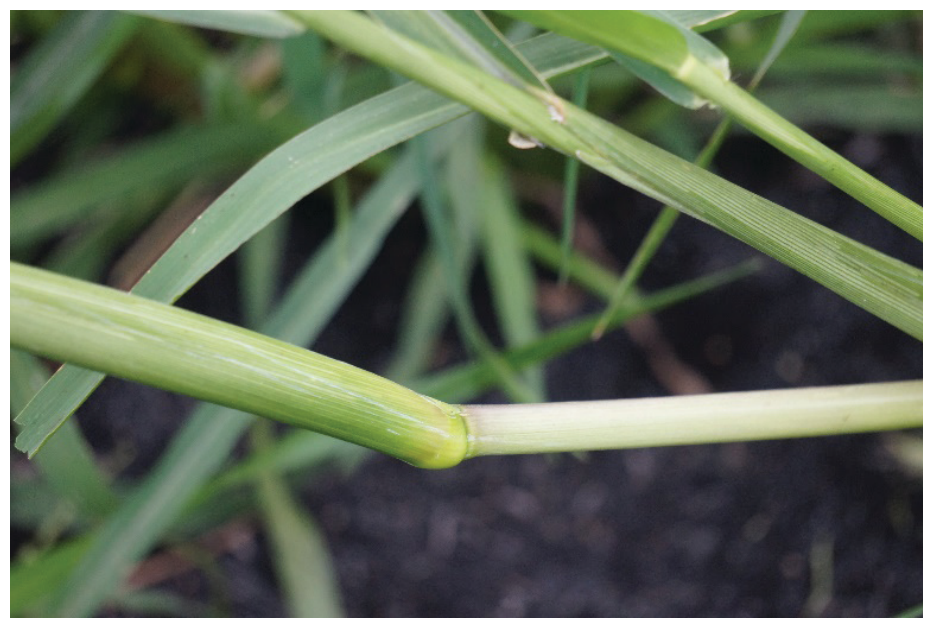

Figure 4. Swollen and bent node of a mature fall panicum plant. Credits: Calvin Odero, UF/IFAS

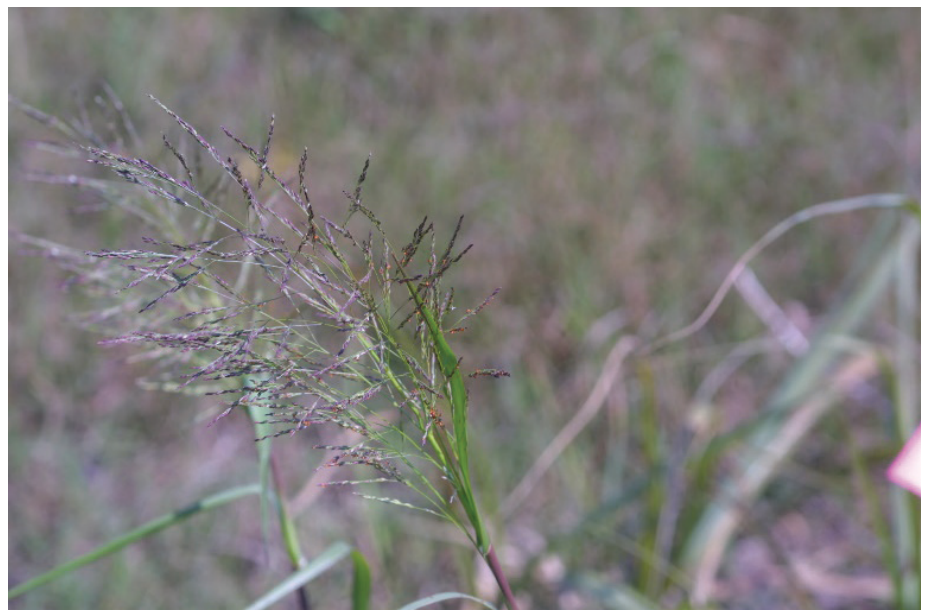

Figure 5. Fall panicum with mature seed head.

Credits: Calvin Odero, UF/IFAS 
Table 1. Preemergence (PRE), very early postemergence (VEPOST), and postemergence (POST) fall panicum control in sugarcane. Contact: Extension weed specialist (dcodero@ufl.edu). This table lists registered pesticides that should be integrated with other pest management methods. Contact your local UF/IFAS Extension office for additional information (https://ifas.ufl.edu/, UF/IFAS locations at the bottom of the webpage).

\begin{tabular}{|c|c|c|c|c|}
\hline $\begin{array}{l}\text { Herbicide Active } \\
\text { Ingredients } \\
\text { (Commonly used } \\
\text { products) }\end{array}$ & $\begin{array}{l}\text { HRAC } \\
\text { MOA }\end{array}$ & $\begin{array}{l}\text { Application } \\
\text { (rate and total/ } \\
\text { year) }\end{array}$ & $\begin{array}{l}\text { Reentry } \\
\text { (hours or days) }\end{array}$ & $\begin{array}{c}\text { Fall Panicum Control, Application Methods, and } \\
\text { Effectiveness } \\
\text { (see product label for details) }\end{array}$ \\
\hline \multicolumn{5}{|c|}{ PREEMERGENCE OR VERY EARLY POSTEMERGENCE } \\
\hline $\begin{array}{l}\text { Atrazine } \\
\text { (Atrazine } 4 \mathrm{~L} \text { or Atrazine } \\
\text { 90DF) }\end{array}$ & $\mathrm{C} 1$ & $\begin{array}{l}6-8 \text { pt/acre for } 4 \mathrm{~L} \\
\text { or } 3.3-4.4 \mathrm{lb} / \mathrm{acre} \\
\text { for } 90 \mathrm{DF} \text {; max. } 20 \\
\text { pt/acre for } 4 \mathrm{~L} \text { or } \\
11.1 \mathrm{lb} \text { for } 90 \mathrm{DF}\end{array}$ & 12 hours & $\begin{array}{l}\text { PRE and VEPOST fall panicum control. If applied VEPOST, } \\
\text { fall panicum should be } 2 \text { inches or fewer in height. It } \\
\text { can also be applied in combination with ametryn (Evik } \\
78.9 D F) \text { at } 0.25-1 \mathrm{lb} / \text { acre. The addition of ametryn can } \\
\text { increase POST activity, but can also result in increased } \\
\text { crop injury to sugarcane. Lower rates of ametryn should } \\
\text { be used when temperatures are warmer. A tank-mix } \\
\text { with pendimethalin (Prowl } 3.3 \mathrm{EC} \text { or Prowl H2O } 3.8 \mathrm{MS} \text { ) } \\
\text { is very effective. Restricted Use. }\end{array}$ \\
\hline $\begin{array}{l}\text { Pendimethalin } \\
\text { (Prowl 3.3 EC or Prowl H2O } \\
\text { 3.8 MS) }\end{array}$ & $\mathrm{K} 1$ & $\begin{array}{c}4.8-9.7 \mathrm{pt} / \mathrm{acre} \text { for } \\
3.3 \mathrm{EC} \text { or } 4.2-8.4 \\
\text { pt/acre for } 3.8 \mathrm{MS} \text {, } \\
\text { max. } 14.4 \mathrm{pt} / \mathrm{acre} \\
\text { for } 3.3 \mathrm{EC} \text { or } 12.5 \\
\text { pt/acre for } 3.8 \mathrm{MS}\end{array}$ & 24 hours & $\begin{array}{l}\text { PRE fall panicum control. Pendimethalin does not have } \\
\text { POST activity. Apply at time of planting or ratooning, } \\
\text { but prior to emergence. Can be combined with atrazine } \\
\text { (Atrazine 4L or Atrazine 90DF) or metribuzin (Tricor } \\
\text { 75DF or Tricor 4F). Mechanical incorporation or rainfall } \\
\text { within } 7 \text { days of application is needed to incorporate } \\
\text { pendimethalin applied alone or in combination with } \\
\text { metribuzin or atrazine into the soil, or activity will be } \\
\text { significantly decreased. Combination with metribuzin } \\
\text { can only be used on muck soils and not sand soils. }\end{array}$ \\
\hline $\begin{array}{l}\text { Metribuzin } \\
\text { (Tricor 75DF or Tricor 4F)' }\end{array}$ & $\mathrm{C} 1$ & $\begin{array}{l}1.33-2.67 \mathrm{lb} \text { for } \\
75 \mathrm{DF} \text { or } 2-4 \mathrm{pt} / \\
\text { acre, max. } 2.67 \mathrm{lb} / \\
\text { acre for } 75 \mathrm{DF} \text { or } 4 \\
\text { pt/acre for } 4 \mathrm{~F}\end{array}$ & 12 hours & $\begin{array}{l}\text { PRE or VEPOST fall panicum control. If applied VEPOST, } \\
\text { fall panicum should be } 2 \text { inches or fewer in height. } \\
\text { Metribuzin in combination with pendimethalin (Prowl } \\
3.3 \text { EC or Prowl H2O } 3.8 \mathrm{MS} \text { ) can improve fall panicum } \\
\text { control. Do not apply on sand soils. }\end{array}$ \\
\hline $\begin{array}{l}\text { S-metolachlor + atrazine }+ \\
\text { mesotrione } \\
(\text { Lumax } 3.674 \mathrm{EZ})\end{array}$ & $\mathrm{K} 3+\mathrm{C} 1+\mathrm{F} 2$ & $\begin{array}{l}2.75-3.75 \mathrm{qt} / \\
\text { acre, max. } 3.75 \mathrm{qt} / \\
\text { acre for PRE only } \\
\text { application }\end{array}$ & 24 hours & $\begin{array}{l}\text { Apply prior to planting, PRE after new plantings, or after } \\
\text { harvest, but prior to re-emergence of ratoon cane for } \\
\text { fall panicum control. If fall panicum has emerged (for } \\
\text { VEPOST), add a crop oil concentrate (COC) at } 1 \% \mathrm{v} / \mathrm{v} \\
\text { or a nonionic surfactant (NIS) at } 0.25 \% \mathrm{v} / \mathrm{v} \text { to the spray } \\
\text { solution. In addition to COC or NIS, a spray-grade UAN } \\
\text { (e.g., } 28-0-0 \text { ) at } 2.5 \% \mathrm{v} / \mathrm{v} \text { or ammonium sulfate (AMS) at } \\
8.5 \mathrm{lb} / 100 \text { gallons of spray solution can be added to the } \\
\text { spray solution. Restricted Use. }\end{array}$ \\
\hline $\begin{array}{l}\text { Clomazone } \\
\text { (Command 3ME) }\end{array}$ & F3 & $\begin{array}{l}2.66-3.3 \mathrm{pt} / \mathrm{acre} \\
\max .3 .33 \mathrm{pt} / \mathrm{acre}\end{array}$ & 12 hours & $\begin{array}{l}\text { PRE fall panicum control. Bleaching of sugarcane leaves } \\
\text { can occur if the crop is spiking at application. Higher } \\
\text { rates should be used on muck soils while lower rates } \\
\text { should be used on sand soils. }\end{array}$ \\
\hline \multicolumn{5}{|c|}{ POSTEMERGENCE } \\
\hline $\begin{array}{l}\text { S-metolachlor }+ \text { atrazine }+ \\
\text { mesotrione } \\
(\text { Lumax 3.674 EZ) }\end{array}$ & $\mathrm{K} 3+\mathrm{C} 1+\mathrm{F} 2$ & $\begin{array}{l}1.5-3.0 \mathrm{qt} / \mathrm{acre}, \\
\max .3 .0 \mathrm{qt} / \mathrm{acre}\end{array}$ & 24 hours & $\begin{array}{l}\text { Apply before sugarcane reaches } 20 \text { inches in height. } \\
\text { Applications can be made over-the-top or post-directed } \\
\text { to actively growing fall panicum. Fall panicum should } \\
\text { be } 3 \text { to } 4 \text { inches or less in height. If PRE application } \\
\text { was made earlier in the season (not to exceed } 3.75 \text { qt/ } \\
\text { acre), only } 1.5 \mathrm{qt} / \text { acre may be applied POST. The total } \\
\text { amount of applied (PRE + POST) cannot exceed } 5.25 \mathrm{qt} / \\
\text { acre/year. Add COC at } 1 \% \mathrm{v} / \mathrm{v} \text { or NIS at } 0.25 \% \mathrm{v} / \mathrm{v} \text { to the } \\
\text { spray solution. In addition to COC or NIS, a spray-grade } \\
\text { urea ammonium nitrate (UAN, e.g., } 28-0-0 \text { ) at } 2.5 \% \mathrm{v} / \mathrm{v} \\
\text { or AMS at } 8.5 \mathrm{lb} / 100 \text { gallons of spray solution can be } \\
\text { added to the spray solution. Restricted Use. }\end{array}$ \\
\hline
\end{tabular}




\begin{tabular}{|c|c|c|c|c|}
\hline $\begin{array}{l}\text { Herbicide Active } \\
\text { Ingredients } \\
\text { (Commonly used } \\
\text { products) }\end{array}$ & $\begin{array}{l}\text { HRAC } \\
\text { MOA }\end{array}$ & $\begin{array}{l}\text { Application } \\
\text { (rate and total/ } \\
\text { year) }\end{array}$ & $\begin{array}{c}\text { Reentry } \\
\text { (hours or days) }\end{array}$ & $\begin{array}{l}\text { Fall Panicum Control, Application Methods, and } \\
\text { Effectiveness } \\
\text { (see product label for details) }\end{array}$ \\
\hline $\begin{array}{l}\text { Topramezone } \\
\text { (Armezon 2.8EC) }\end{array}$ & $\mathrm{F} 2$ & $\begin{array}{l}0.5-2.0 \mathrm{fl} \text { oz/acre, } \\
\max .4 \mathrm{fl} \text { oz/acre }\end{array}$ & 12 hours & $\begin{array}{l}\text { Can be applied during the fallow period before } \\
\text { sugarcane planting to } 100 \text { days before harvest. Efficacy } \\
\text { is greater on fall panicum shorter than } 12 \text { inches in } \\
\text { height. If fall panicum is taller than } 12 \text { inches, apply } \\
\text { at } 2 \text { fl oz/acre; however, combination with asulam } \\
\text { provides better control of this size of fall panicum. } \\
\text { Combinations with atrazine (Atrazine } 4 \mathrm{~L} \text { or Atrazine } 90 \\
\text { DF) or metribuzin (Tricor } 75 \text { DF or Tricor } 4 \mathrm{~F} \text { ) improve fall } \\
\text { panicum control. Multiple sequential applications at } \\
2 \text { - to 3-week intervals may be necessary for best control } \\
\text { of larger fall panicum. Apply using methylated seed oil } \\
\text { (MSO) or COC at } 1-1.5 \% \text { v/v plus nitrogen fertilizer (AMS } \\
\text { at } 8.5-17 \text { lb/100 gallons of water or UAN at } 1.25-2.5 \\
\text { gallons/100 gallons of water). }\end{array}$ \\
\hline $\begin{array}{l}\text { Asulam } \\
\text { (Asulox } 3.34 \text { SC) }\end{array}$ & I & $\begin{array}{l}6-8 \mathrm{pt} / \mathrm{acre}, \max . \\
16 \mathrm{pt} / \mathrm{acre}\end{array}$ & 12 hours & $\begin{array}{l}\text { Over-the-top POST or post-directed on sugarcane at } \\
\text { least } 14 \text { inches tall for fall panicum control. Application } \\
\text { may also be banded, semi-directed, or applied as spot } \\
\text { treatment. Use higher rate for fall panicum greater than } \\
12 \text { inches tall for rescue control. Control is improved } \\
\text { with addition of NIS at } 0.25-0.5 \% \mathrm{v} / \mathrm{v} \text { or COC at } 1 \% \mathrm{v} / \mathrm{v} \text {. } \\
\text { Addition of a buffer may be beneficial for water } \mathrm{pH} \\
\text { above } 9 . \text { Apply when air temperature is at least } 60^{\circ} \mathrm{F} \\
\text { for efficacy. Combination with trifloxysulfuron-sodium } \\
\text { (Envoke } 75 \mathrm{DF} \text { ) or topramezone (Armezon } 2.8 \mathrm{EC} \text { ) will } \\
\text { improve control of fall panicum greater than } 12 \text { inches } \\
\text { tall. }\end{array}$ \\
\hline $\begin{array}{l}\text { Trifloxysulfuron-sodium } \\
\text { (Envoke 75DF) }\end{array}$ & B & $\begin{array}{l}0.3-0.6 \mathrm{oz} / \mathrm{acre}, \\
\max .1 .5 \mathrm{oz} / \mathrm{acre}\end{array}$ & 12 hours & $\begin{array}{l}\text { Apply at } 0.3 \text { oz/acre to control fall panicum below } 6 \\
\text { inches in height. Apply over-the-top or as a directed } \\
\text { spray. For ratoon cane, over-the-top applications can } \\
\text { be made until sugarcane reaches } 24 \text { inches in height. } \\
\text { The } 0.6 \text { oz/acre rate may be applied as directed spray } \\
\text { to sugarcane that is more than } 18 \text { inches tall through } \\
\text { lay-by. For control of larger (e.g., } 7-18 \text { inches) fall } \\
\text { panicum plants, trifloxysulfuron-sodium (Envoke 75DF) } \\
\text { at } 0.3 \text { oz/acre can be tank-mixed with } 4 \text { pt/acre asulam } \\
\text { (Asulox } 3.34 S C \text { ) and applied broadcast to ratoon cane. } \\
\text { Trifloxysulfuron-sodium should always be applied } \\
\text { with NIS at } 0.25 \% \text { v/v. Do not apply within } 100 \text { days of } \\
\text { sugarcane harvest. }\end{array}$ \\
\hline \multicolumn{5}{|c|}{$\begin{array}{l}\text { 'WARNING: The following information has been added to the atrazine and metribuzin labels. This statement should be heeded by all } \\
\text { prospective users and steps should be taken to comply with this label change: } \\
\text { "Atrazine and metribuzin are chemicals which can travel (seep or leach) through soil and can contaminate groundwater as a result of } \\
\text { agricultural use. Atrazine and metribuzin have been found in groundwater as a result of agricultural use. Users are advised not to apply } \\
\text { atrazine or metribuzin where the water table (groundwater) is close to the surface and where the soils are very permeable, i.e., well-drained } \\
\text { soils such as sands and loamy sands. Your local agricultural agencies can provide further information on the type of soil in your area and } \\
\text { location of groundwater. In addition, some product label statements include as a further qualification of risky soils, soils containing sinkholes } \\
\text { over limestone bedrock, severely fractured surfaces, and substrates which would allow direct introduction into an aquifer." }\end{array}$} \\
\hline
\end{tabular}

